\title{
Rapid Molecular Identification of Tetraselmis Using Enzymatic Digestion of the 18S rDNA Gene
}

\author{
Janeth Galarza ${ }^{1}$,, Kevin Crespín ${ }^{1}$, Carolina Tufiño ${ }^{2}$ \\ ${ }^{1}$ Biology Research Center, Faculty of Marine Sciences, Santa Elena Peninsula State University, La Libertad, Ecuador \\ ${ }^{2}$ Laboratory of Marine Physiology and Genetics, Center for Advanced Studies in Arid Zones, Coquimbo, Chile
}

Email address:

jgalarza@upse.edu.ec(J. Galarza)

${ }^{*}$ Corresponding author

\section{To cite this article:}

Janeth Galarza, Kevin Crespín, Carolina Tufiño. Rapid Molecular Identification of Tetraselmis Using Enzymatic Digestion of the $18 S$ rDNA Gene. International Journal of Genetics and Genomics. Vol. 8, No. 3, 2020, pp. 114-119. doi: 10.11648/j.ijgg.20200803.14

Received: July 18, 2020; Accepted: August 17, 2020; Published: September 24, 2020

\begin{abstract}
Tetraselmis is a genus of quadriflagellated single-celled green algae belonging to the Phylum Chlorophyta, commonly used in aquaculture with very promising biotechnological potential. The varied morphological characteristics, in some cases, have led to confusion in taxonomic identification. To solve this problem, new techniques based on molecular markers and restriction enzymes can ensure the identification of microalgae without sequencing. This study aimed to compare in silico modeling with an experimental restriction pattern based on the 18S rDNA gene for the identification of a microalgae strain. The strain grew in a culture medium, based on organic fertilizer. Theoretical analyses allowed the design of three primers based on the alignment of eight sequences obtained from NCBI, applying the Geneious Prime ${ }^{\circledR} 2019$ and V1.3 and Oligo Calculator version 3.2. programs. The in silico restriction patterns was obtained with the NEBcutter v2.0 program. Experimental analyses began with the extraction of the DNA using the TENS protocol, then PCR amplification using PM016F/PM-016R and PM-001F/PM-016R primers of $18 S \mathrm{rDNA}$ and finally the product was digested with $B b v C I$ and $E c o 53 \mathrm{kI}$; $B s t U I, R s a I$ and $M s p I$ enzymes. The DNA concentration extraction reached $3200 \mathrm{ng}^{\mathrm{l}^{-1}}$ and a purity of 2.0. The PCR amplified two products: $950 \mathrm{bp}$ and $1400 \mathrm{bp}$, which brought us closer to identifying the microalgae. The in silico modeling and experimental restriction patterns showed similar fragments. In this way, the efficient response of restriction enzymes was demonstrated by confirming that the PM013 strain corresponds to the Tetraselmis genus. This method can be considered as a fast and safe alternative to identify wild microalgae in a basic molecular biology laboratory.
\end{abstract}

Keywords:

\section{Introduction}

Tetraselmis (Class Chlorodendrophyceae) is a genus of microalgae that has been considered an industrial source, due to the content of proteins, vitamins, lipids, carbohydrates, fatty acids and bioactive compounds. Tetraselmis can influence the growth and survival of fish and crustaceans because of its antioxidant properties [1]. It also accumulates many attractive oils and starches for the production of biofuels [2].

Morphologically, Tetraselmis is an ovoid green cell covered by a solid wall called teak. It has a single large chloroplast and four identical flagella in two different pairs; they can form colonies during some stage of their life cycle
[3]. Species of this genus have been found in marine and freshwater ecosystems worldwide [4]. These morphological characteristics observed through light and electron microscopy have been the basis for taxonomic studies of microalgae $[5,6]$.

During their life cycle, the genus Tetraselmis, acquires complex cellular characteristics that lead to confusion between taxa, but it has been insufficient for its identification [7-9]. Important results improved since the 90's, when the taxonomy of algae introduced the application of phylogenetic analyzes with molecular markers $[5,10]$.

Several molecular markers have been utilized to identify 
microalgae such as: $r c b L, I T S 1, I T S 2,18 S \mathrm{rDNA}$, 23S rDNA $[6,11,12]$. The $18 S$ rDNA gene is the most widely used, because its sequence has highly conserved flanking regions and repetitive arrangements which establish the phylogenetic relationship within distant organisms and between lineages and Phylum [4,13,10,14]. In this way, Chlorella sorokiniana [15], Tetraselmis indica [4], Dunaliella salina [8] and diatoms [16] were identified.

Commonly, the identification of genes is realized with DNA extraction, the amplification of a specific product and its sequencing $[17,18,14]$. However, mapping genes, using restriction enzymes, generates fast and reliable results instead of sequencing [19]. Bioinformatics programs can predict restriction patterns through in silico modeling, which is based on the sequence of the molecular marker and the relative location of the restriction sites for different enzymes [20-21]. In silico modeling provides the size of the DNA fragments and can subsequently be validated experimentally $[22,19]$.

This work is being proposed to compare in silico modeling with experimental restriction patterns based on the $18 \mathrm{~S} r D N A$ gene for the identification of a microalgae strain isolated from the Santa Elena Peninsula - Ecuador, morphologically identified as Tetraselmis.

\section{Materials and Methods}

\subsection{Microalgae Strain and Cultivation}

The sample was obtained from the Santa Elena Peninsula, Ecuador $\left(2^{\circ} 11^{\prime} 36.7\right.$ "S $\left.80^{\circ} 59 ' 10.0^{\prime \prime} \mathrm{W}\right)$ and registered with the code PM013 corresponding to the project INCYT-PNF2017M3121. The strain was cultivated following a previous methodology [23]. The culture medium was prepared in 200 $\mathrm{ml}$ bottles based on an organic fertilizer ( $2 \%$ NPK) (Marchfoltm), containing sodium metasilicate as an inorganic source and enriched with vitamins $\left(1 \mathrm{ml} \mathrm{l}^{-1}\right)$. The cultures were installed in triplicate for six days under the following conditions: temperature of $24 \pm 0.5^{\circ} \mathrm{C}$, a photon flux density of $60 \mu \mathrm{mol} \mathrm{m} \mathrm{m}^{-2} \mathrm{~s}^{-1}$, provided by white light fluorescent lamps (Sylvania 18W), photoperiod 12/12 hours (light/dark), $\mathrm{pH} 7$, shake manually twice daily, following a previous protocol [24]. Biomass was obtained by centrifugation at $13000 \mathrm{rpm}$.

\subsection{Theoretical Molecular Analysis}

\subsubsection{Aligments and Primers Design}

Eight sequences of the $18 S$ rDNA gene were selected from GenBank and aligned with the Clustal method using the ClustalW Alignment v2.0.12 program to obtain a conserved region and from this alignment, three Tetraselmis specific primers were designed: PM-001F Forwards (5'-GAGTGTTCAAAGCAAGCCTACG -3'), PM-016F Forwards (5'- AGAAACGGCTACCACATCCA -3') and PM-016R Reverse (5'TGTACAAAGGGCAGGGACGTAATC-3 '), using Geneious Prime ${ }^{\circledR} 2019$ software. $\quad$ v1.3 and Oligo Calculator v3.27 [25].

\subsubsection{In Silico Modeling of the $18 S \mathrm{rDNA}$ Gene}

To obtain the Tetraselmis in silico restriction pattern, we used the consensus sequence from the $18 \mathrm{~S} r \mathrm{DNA}$ and it was analyzed by the BioEdit program Map restriction and NEBcutter v2.0. The enzymes BstUI, MspI, Rsal, BbvCI and Eco53kI were selected.

\subsection{Experimental Molecular Analysis}

\subsubsection{Total DNA Extraction}

The extraction of the total DNA was carried out using a modifying TENS protocol [26]. In an eppendorf tube, $50 \mathrm{mg}$ of Tetraselmis, $600 \mu \mathrm{l}$ of TENS buffer and $2 \mu$ of proteinase $\mathrm{K}$ were added and the solution was incubated at $37^{\circ} \mathrm{C}$ for $15 \mathrm{~min}$. Then $200 \mu \mathrm{l}$ of phenol and $200 \mu \mathrm{l}$ of chloroform: isoamyl alcohol (24:1) was added and centrifuged at $10000 \mathrm{rpm}$ for 10 minutes, the supernatant was transferred to a new tube containing $500 \mu \mathrm{l}$ of $95 \%$ ethanol frozen, the sample was left to rest at $-20^{\circ} \mathrm{C}$ for $30 \mathrm{~min}$ and subsequently centrifuged. The pellet was washed with $800 \mu \mathrm{l}$ of $75 \%$ ethanol frozen and finally resuspended in $100 \mu \mathrm{l}$ of UltraPure TM Water. The extracted DNA went through a purification process with sodium acetate (3M, pH 5.2) [27]. Then it was measured by spectrophotometry at an $\mathrm{A}_{260} / \mathrm{A}_{280}$ wavelength with a $2000 \mathrm{cc}$ Nanodrop.

\subsubsection{PCR Amplification}

PCR experiments were carried out using primers PM-016F and PM-016R; other with PM-001F and PM-016R. The PCR reactions were performed in a total volume of $15 \mu \mathrm{l}$, containing $25 \mathrm{ng}$ of genomic DNA, $0.125 \mathrm{mM}$ of each primer, $0.2 \mathrm{mM}$ of dNTPs, $3 \mathrm{mM}$ of $\mathrm{MgCl}_{2}, 1 \mathrm{U}$ Taq DNA Polymerase and Buffer $1 \mathrm{X}$ (All products from Invitrogen ${ }^{\mathrm{TM}}$ ) [28]. The PCR conditions were as follows: an initial denaturation of the template DNA at $94^{\circ} \mathrm{C}$ for $10 \mathrm{~min}$, followed by 35 cycles of $94^{\circ} \mathrm{C}$ for $40 \mathrm{~s}, 61^{\circ} \mathrm{C}$ for $30 \mathrm{~s}$ and $72^{\circ} \mathrm{C}$ for $1 \mathrm{~min} 30 \mathrm{~s}$, and finished with a final extension at $72^{\circ} \mathrm{C}$ for 5 minutes using a thermal cycler (Bio-Rad T100). The PCR fragments were separated by $1 \%$ agarose gel electrophoresis with $0.5 \mathrm{X}$ GelRed (Biotium).

\subsubsection{Digestion of the PCR Product}

The PCR product was digested with the enzymes $B b v C I$ and Eco53kI for the first reaction; BstUI, MspI and Rsal for the second. All enzymes were from Invitrogen ${ }^{\mathrm{TM}}$ and the performance was according to a previous protocol [19]. $10 \mu 1$ of the PCR product was used for the enzyme reaction (1U/enzyme) in a final volume of $50 \mu$. The sample was incubated at $37^{\circ} \mathrm{C}$ for 2 hours. The product was run on a $1 \%$ agarose gel electrophoresis, with $\operatorname{Sybr}{ }^{\circledR}$ Green staining and visualized in an UV Transilluminator.

\section{Results}

\subsection{Sequence Alignment and Primer Design}

In order to determine the conserved region of the $18 \mathrm{~S}$ rDNA gene, we selected eight pre-established sequences related to Tetraselmis, and we analyzed the genetic 
relationship. The alignment showed that the species share a high percentage of similarity (99\%) (Table 1). The conserved region was evident from $380 \mathrm{bp}$ to $1680 \mathrm{bp}$.

Based on the conserved region, we designed three primers
(PM-016F, PM-016R and PM-004F) to identify the Tetraselmis genus. The Geneious Prime ${ }^{\circledR} 2019$ program V1.3 and Oligo Calculator v3.27 provided the optimal characteristics of the primers (Table 2).

Table 1. Sequences of the genus Tetraselmis from GenBank used in this study.

\begin{tabular}{llll}
\hline Sequences & $\mathbf{N}^{\mathbf{0}}$ (bp) & Similarity data (\%) & $\mathbf{N}^{\mathbf{0}}$ Access (Genbank) \\
\hline Tetraselmis sp. & 1674 & 100 & GQ917221.1 \\
Tetraselmis chuii & 1751 & 99.94 & 100 \\
Tetraselmis sp. & 1701 & 903999.1 & AJ431370.2 \\
Tetraselmis carteriiformis & 1641 & 99.24 & FJ559384.1 \\
Tetraselmis striata & 1674 & 99.26 & JQ315739.1 \\
Tetraselmis suecica & 1674 & 90 & JF489949.1 \\
Tetraselmis subcordiformis & 1719 & 99.01 & KU561107.1 \\
Tetraselmis marina & 1669 & 99.77 & KY045847.1 \\
\hline
\end{tabular}

Table 2. Characteristics of the primers designed for the amplification of the Tetraselmis $18 S$ rDNA gene.

\begin{tabular}{|c|c|c|c|c|c|c|c|}
\hline Reaction & Primer & Sequences $\left(5^{`} \rightarrow 3^{\prime}\right)$ & Lenght (bp) & $\mathbf{G}+\mathbf{C}(\%)$ & $\mathbf{T m}^{1}\left({ }^{\circ} \mathrm{C}\right)$ & $\mathbf{T a}^{2}\left({ }^{\circ} \mathbf{C}\right)$ & Product length (bp) \\
\hline \multirow{2}{*}{1} & PM-016F & AGAAACGGCTACCACATCCA & 20 & 50 & 59 & \multirow{2}{*}{61} & \multirow{2}{*}{1400} \\
\hline & PM-016R & TGTACAAAGGGCAGGGACGTAATC & 24 & 50 & 62 & & \\
\hline \multirow{2}{*}{2} & PM-001F & GAGTGTTCAAAGCAAGCCTACG & 22 & 50 & 61 & \multirow{2}{*}{59} & \multirow{2}{*}{950} \\
\hline & PM-016R & TGTACAAAGGGCAGGGACGTAATC & 24 & 50 & 62 & & \\
\hline
\end{tabular}

${ }^{1}$ Tm: temperature medium theoretical

${ }^{2}$ Ta: temperature hybridization used in this study

\subsection{Quality of DNA Extracted and Amplification by PCR}

The quality of the extracted DNA was $3200 \mathrm{ng} \mu \mathrm{l}^{-1}$ and its purity was 2.0 under the absorbance ratio $\mathrm{A}_{260} / \mathrm{A}_{280}$. Due to high concentration of DNA, it was diluted $(1: 25)$ to be used in PCR amplification.

From the theoretical analysis, the size of the first PCR product was 1400 bp with PM-016F/PM-016R and the second product was $950 \mathrm{bp}$ with $\mathrm{PM}-001 \mathrm{~F} / \mathrm{PM}-016 \mathrm{R}$. This would allow the amplification of much of the length of the $18 S$ rDNA in Tetraselmis species. The experimental results displayed the same desired bands (Figures 1 and 2), demonstrating that the PM013 strain would correspond to the Tetraselmis genus.

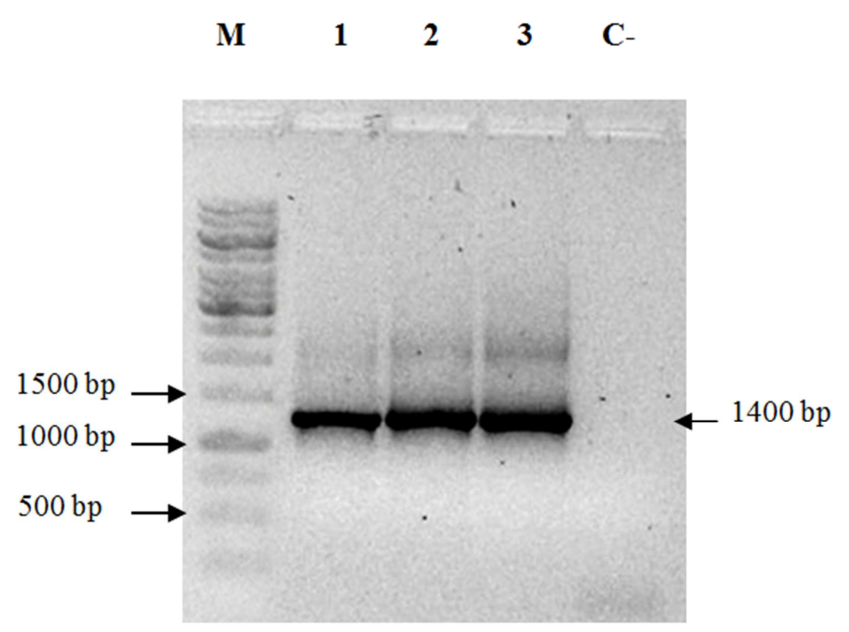

Figure 1. PCR of $18 S$ rDNAs amplified with PM-016F/PM-016R primers. Lanes 1 to 3: different samples of Tetraselmis (PM013). C-: negative control M: molecular weight marker (1kb Invitrogen ${ }^{T M}$ ). Right arrow indicates the size of the fragment.

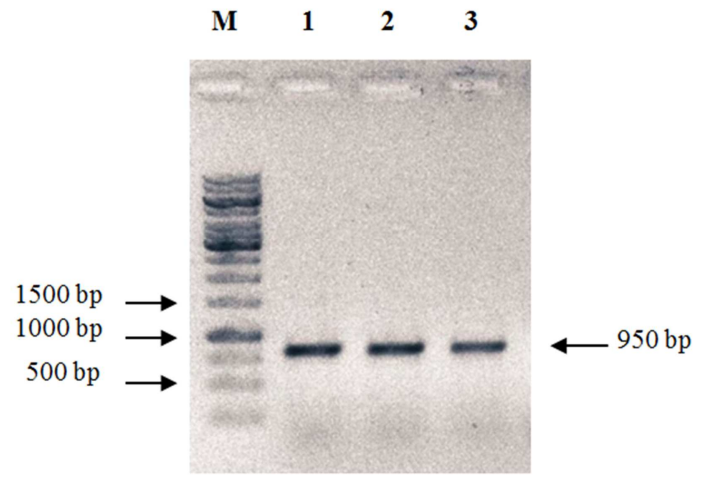

Figure 2. PCR of $18 S$ rDNAs amplified with PM-001F/PM-016R primers. Lanes 1 to 3: different samples of Tetraselmis (PM013). M: molecular weight marker (1kb Invitrogen $\left.{ }^{T M}\right)$. Right arrow indicates the size of the fragment.

\subsection{Comparison of the in Silico Versus Experimental Restriction Pattern}

The enzymes $B b v C I$ and Eco53kI digested a PCR product of the first reaction and the enzymes BstUI, RsaI and MspI digested the second reaction. The in silico modeling predicted restriction patterns where each enzyme made more than two cuttings along it (Figure 3A and 4A).

The experimental restriction patterns showed fragments of similar sizes to the in silico modeling. The BbyCI performed two cuttings: $900 \mathrm{bp}$ and $500 \mathrm{bp}$, while Eco53kI produced a fragment of $1000 \mathrm{bp}$ and the other of $400 \mathrm{bp}$. The BstUI revealed three cuttings: a $700 \mathrm{bp}$ fragment and another of approximately $200 \mathrm{bp}$; the $50 \mathrm{bp}$ fragment was unseen. The RsaI enzyme produced two cuttings, the largest fragment was $900 \mathrm{bp}$ and the small fragment was unseen in the $1 \%$ agarose gel. The MspI generated three cuttings, a 400 bp fragment and two overlapping fragments of approximately $250 \mathrm{bp}$, 
while the smallest fragment was impossible to show (Figure $\quad 3 \mathrm{~B}$ and $4 \mathrm{~B}$ ).

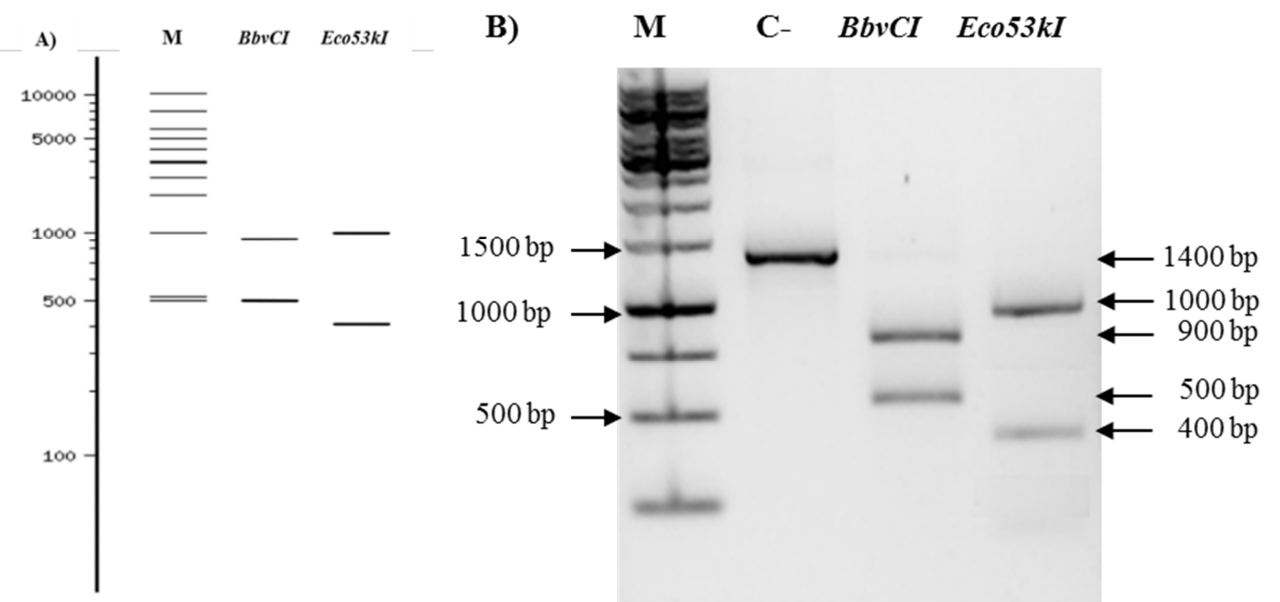

Figure 3. A) In silico modeling of the restriction pattern of the $18 S$ rDNA gene Tetraselmis digested with BbvCI and Eco53kI enzymes. B) Experimental restriction pattern of the $18 \mathrm{~S}$ rDNA gene digested with BbvCI and Eco53kI enzymes. C-: undigested PCR product; M: molecular weight marker (1Kb Invitrogen ${ }^{T M}$ ) $1 \%$ agarose gel. The arrows indicate the size of the fragments.
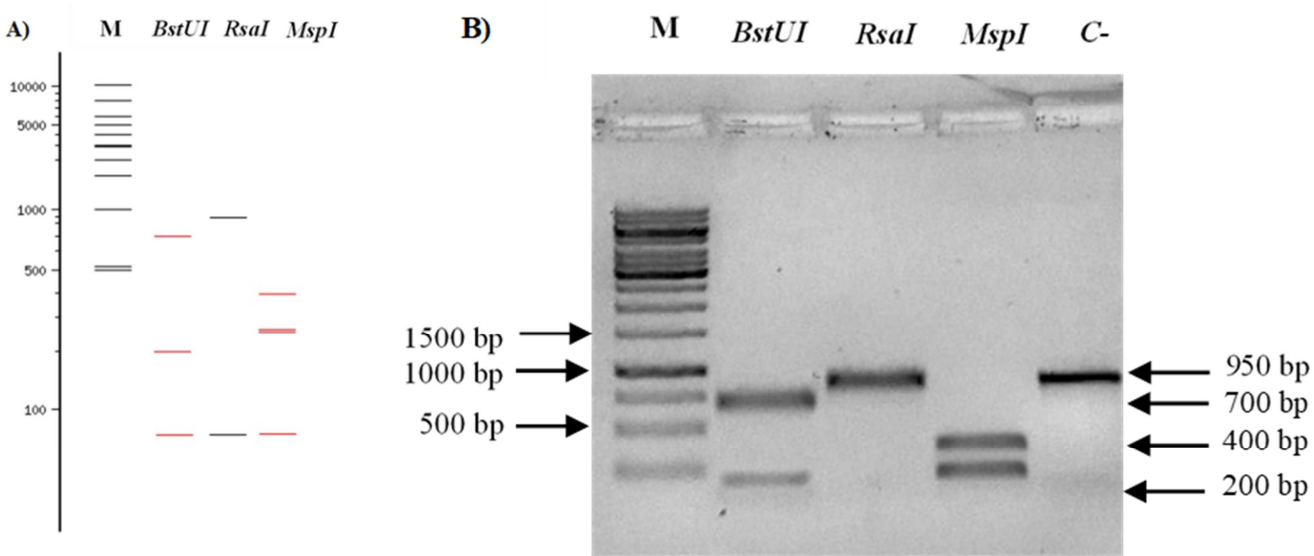

Figure 4. A) In silico modeling of the restriction pattern of the $18 S \mathrm{rDNA}$ gene Tetraselmis digested with BstUI, RsaI and MspI enzymes. B) Experimental restriction pattern of the $18 S$ rDNA gene digested with BstUI, RsaI and MspI enzymes. C-: undigested PCR product; M:-molecular weight marker (1Kb Invitrogen ${ }^{T M}$ ) $1 \%$ agarose gel. The arrows indicate the size of the fragments.

\section{Discussion}

We identified a Tetraselmis sp. microalgae strain isolated from the Santa Elena Peninsula, Ecuador, and compared it with in silico modeling and experimental restriction patterns based on the $18 S$ rDNA gene.

The sequence comparison allows us to infer that the similarity and evolution grade of a new molecule can be based on a database such as NCBI [29, 30]. Taking advantage of the existing information, we performed the alignment of eight sequences of the $18 S \mathrm{rDNA}$ gene from various Tetraselmis species, to find the conserved region; this allowed us to obtain a more reliable result with real data. Furthermore, according to a previous work [13], sequence conservation is one of the most direct ways of estimating the precision of an alignment in computational biological models and the use of a bioinformatic program that provides us with accurate data such as Clustal W Alignment v2.0.12.

The conserved region of the Tetraselmis $18 S$ rDNA gene facilitated the design of the three primers (PM-016F, PM-
016R and PM-001F) used in this study. According to a previous work, primer design should start with sequence alignment to ensure specificity [34].

The size of the $18 S$ rDNA gene in Tetraselmis has been described previously, and it oscillates around 2500 bp [32]. However, other studies found PCR products between 1000 bp and $1500 \mathrm{bp}[33,34,28]$. This evidence agrees with our results, because we amplified two products, one of $950 \mathrm{bp}$ and the other of $1400 \mathrm{bp}$, this fact allowed us to take steps toward the molecular identification of the PM013 strain as a Tetraselmis sp.

A strong PCR amplification also depends on the quality of the template DNA. The TENS protocol has been efficient for the extraction of total DNA in microorganisms, especially in microalgae, because it contributes to the proteins denaturation of the cell wall that causes a total lysis of the cell [35], high concentration and purity [31, 26, 34]. We obtained DNA of high quality in concentration and purity which we recommend for molecular studies of microalgae.

In this era of new knowledge, the molecular identification 
has contributed to deciphering species at any stage of their life cycle $[9,17,16]$. The PCR product has been generally sequenced and evaluated using bioinformatic programs that ensure the functional or phylogenetic relationship $[13,16$, 14]. However, the benefit of using restriction enzymes could be an alternative technique based on the PCR product and is faster and reliable [21, 28, 19]. For example, Olmos, et al. (2000) implemented this technique in the molecular identification of Dunaliella sp [8]; while Chin, et al. (2018) and Pillacela, et al. (2020) performed an in silico analysis to obtain the restriction pattern before being experimentally evaluated Pyrodinium bahamense [34] and Haematococcus sp [19], respectively.

In our study, we predicted the in silico restriction patterns for two PCR products, and then we digested experimentally using the enzymes BbvCI and Eco53kI; BstUI, RsaI, and MspI. The results were satisfactory, the experimental restriction patterns were highly related to the in silico modeling, although small fragments $(<100 \mathrm{bp})$ were unseen because they correspond to the ends of the sequence, left by the restriction enzymes cuttings, and are generally imperceptible and lack biological validity. The same variations were presented by Pillacela, et al. (2020) and Cienfuegos, et al. (2008) [19, 39].

Currently, in silico modeling is important in molecular biological studies [36, 18] because they predict reliable results and save time and money in the experimental stage $[37,38]$. The high similarity between the restriction patterns obtained in silico and experimentally demonstrated the veracity of the results. This suggests the PM013 strain, isolated from the Santa Elena Peninsula Ecuador, is related to Tetraselmis sp. In addition, laboratories can work in basic molecular biology to identify organisms at the genus level.

\section{Conclusions}

Theoretical analyses allowed to find the conserved region of the Tetraselmis $18 S$ rDNA gene, thus it facilitated the design of primers PM-016F/PM-016R and PM-001F/PM-016R, which provided PCR products of $1400 \mathrm{bp}$ and $950 \mathrm{bp}$, respectively. We could show similar fragments between the in silico modeling and experimental restriction patterns after the enzymes $B b v C I$ and Eco53kI; BstUI, RsaI and MspI digested each product, which confirms that the PM013 strain corresponds to the Tetraselmis sp. Those results were supported by high quality DNA obtained with the TENS protocol, which allows us to suggest its usefulness in molecular biology studies of the Tetraselmis. Finally, we infer that bioinformatics applications and in silico modeling are essential before experimental tests of biological processes, in this work they allowed us a fast and effective response of restriction enzymes when carrying out molecular identification in a basic laboratory where sequencing work is difficult.

\section{Acknowledgements}

This research was supported by the Center for
Advanced Studies of Arid Zones (CEAZA-Chile) through Dr. Claudio Álvarez and financed by the INCYT-PNF2017M3112 Projects (Ecuador); UPSE-CUP: 91870000.0000 .384095 (Ecuador), with the permission of the Ministry of the Environment: MAE-DNB-CM-CM2018-0099. We thank the MsC. Jimmy Villón, and Blgo. Bryan Pillacella for his support in the sampling and cultivation of the microalgae.

\section{References}

[1] Macías, P., Coello, D., \& García, D. (2018). Floración de Tetraselmis sp., en la zona costera frente a las Provincias de Manabí y Santa Elena (Abril 2018). Guayaquil: Instituto Nacional de Pesca.

[2] Úbeda, P., Chileh, T., Dautor, Y., García, F., \& Alonso, D. (2015). Tools for microalgal biotechnology: Development of an optimized transformation method for an industrially promising microalga Tetraselmis chuii. J. Appl. Phycol, 1 (27), 223-232.

[3] Guiry, M., \& Guiry, G. (2018). AlgaeBase. World-wide electronic publication, National University of Ireland, Galway. Recuperado el 11 de Junio de 2019, de World-wide electronic publication, National University of Ireland, Galway: $\mathrm{http}: / / w w w . a l g a e b a s e . o r g$

[4] Arora, Mani. (2016). Tetraselmis: an Introducción. The Botanica, 66. 155-175.

[5] Juliet, B., \& Lewis, J. (2007). Unravelling the algae. the past, present and future of algal systematics. London, UK: Systematics Association special volume series, 75.

[6] Arora, M., Anil, A., Leliaert, F., Delany, J., \& Mesbahi, E. (2013). Tetraselmis indica (Chlorodendrophyceae, Chlorophyta), a new species isolated from salt pans in Goa, India. European Journal of Phycology, 48 (1), 61-78.

[7] Lee, H. \& Hur, S., (2009). Genetic Relationships among Multiple Strains of the Genus Tetraselmis Based on Partial 18S rDNA Sequences. Algae, 24 (4), 205-212.

[8] Olmos, J., Paniagua, J., \& Contreras, R. (2000). Molecular identification of Dunaliella sp. utilizing the 18S rDNA gene. Letters in Applied Microbiology, 80-84.

[9] Zou, S., Fei, C., Wang, C., Gao, Z., Bao, Y., He, M., \& Wang, C. (2016). How DNA barcoding can be more effective in microalgae identification: a case of cryptic diversity revelation in Scenedesmus (Chlorophyceae). Scientific reports, 6, 36822. $10.1038 /$ srep36822.

[10] Tragin, M., Lopes dos Santos, A., Christen, R., \& Vaulot, D. (2016). Diversity and ecology of green microalgae in marine systems: an overview based on $18 \mathrm{~S}$ rRNA gene sequences. Perspectives in Phycology, 3 (3), 141-154.

[11] Kusumawati, L., Wahyudi, R., Pinontoan, R., Gorreti, M., \& Panggabean, L. (2015). Sequence Analysis of 18S DNA of Melosira sp., Dunaliella sp., Isochrysis sp. and Porphyridium sp. The 3rd International Conference on Biological Science 2013, 2, 592-597.

[12] Turmel, M., De Cambiaire, J., Otis, C., \& Lemieux, C. (2016). Distinctive architecture of the chloroplast genome in the chlorodendrophycean green algae scherffelia dubia and Tetraselmis sp. CCMP 881. PLoS ONE, 11 (2), 1-22. 
[13] Chatzou, M., Cedrik, M., Jia Ming, C., Carsten, K., Giovanni, B., Ionas, E., \& Cedric, N. (2016). Multiple sequence alignment modeling: methods and applications. Oxford University, 17 (6), 1009-1023.

[14] Gunapati, O., A. Thadoi., K, Ojit Singh., O, Avijeet Singh., Th, Indrama., Laxmipriya Koijam., Wangkhem, Indira., Chungkham, Silvia., A, Sharma., Romi, Khangembam., Minerva, Shamjetshabam., Th, Bidyababy., K, Sarabati., O.N, Tiwari \& G.D, Sharma (2015). Molecular characterization of selected diazotrophic cyanobacteria of North East India for phylogenetic study Int. J. of Adv. Res. 3 (8). 261-271.

[15] Flores, F., Maldonado, S., \& Ortiz, J. (2016). Identificación molecular de microalgas clorófitas del Ecuador. Research Gate, 1-2.

[16] Benoiston, A.-S., Ibarbalz, F., Bittner, L., Guidi, L., Jahn, O., Dutkiewicz, S., \& Bowler, C. (2017). The evolution of diatoms and their biogeochemical functions. Phil. Trans. $R$. Soc. B, 372 (20160397), 2-10.

[17] Bérard, A., Dorigo, U., Humbert, J., \& Martin, F. (2005). Microalgae community structure analysis based on $18 \mathrm{~S}$ rDNA amplification from DNA extracted directly from soil as a potential soil bioindicator. Agronomy for Sustainable Development, Springer Verlag/EDP Sciences/INRA, 25 (2), 285-291.

[18] Galarza, J., Gimpel, J., Rojas, V., Arredondo-Vega, B., \& Henríquez, V. (2018). Over-accumulation of astaxanthin in Haematococcus pluvialis through chloroplast genetic engineering. Algal Research, 31, 291-297.

[19] Pillacela, B., Galarza, J., \& Tufiño, C. (2020). Reliability of in silico Modeling Based on Restriction Patterns for the Study of the Carotenogenic Gene pds of Haematococcus sp. International Journal of Microbiology and Biotechnology, 5 (1), 16-21.

[20] František, M. (2005). Physical Mapping-Restriction Mapping (4th edition ed.). USA: Molecular Cell Biology.

[21] Vincze, T., Posfai, J., \& Roberts, R. (2003). NEBcutter: a program to cleave DNA with restriction enzymes. Nucleic Acids Res, 31, 3688-3691.

[22] Parashar, D, Srivastava R, Chauhan D, Sharma V, Maharaj Singh, Mallika Lavania, Chauhan A, \& Bhatia A. (2006). Characterization of mycobacteria isolated from bovines by PRA-targetting hsp 65 gene region. J Commun Dis, 38 (2): 263-268.

[23] Garduño-Solórzano, G., Rodríguez, M., Martínez, M., Quintanar, R., Lozano, C., Campos, J., \& Monsalvo, A. (2011). Cultivos de microalgas del Lago de Catemaco, Veracruz. Latinoam Biotecnol Amb Algal, 2 (2), 67-80.

[24] Nagaraj, S., Arulmurugan, P., Rajaram, M., Sundararaj, R., \& Rengasamy, R. 2012. Enhanced production of astaxanthin at different physico-chemical parameters in the green alga Haematococcus pluvialis Flotow. Phykos, 42 (1), 59-71.

[25] Kibbe, W. (2007). Oligo Calc:Oligonucleotide Properties Calculator. Recuperado el 6 de Junio de 2019, de http://biotools.nubic.northwestern.edu/OligoCalc.html.

[26] Green, M., \& Sambrook, J. (2012). Molecular Cloning. New York: Cold Spring Harbor Laboratory Press.

[27] Rocha, P. (2002). Teoría y práctica para la extracción y purificación del ADN de palma de aceite. Bogotá, Colombia: Laboratorio de Marcadores Moleculares, Área de Fisiología y Mejoramiento.

[28] Yáñez, R. (2011). Categorización taxonómica en base a marcadores moleculares de microalgas extremófilas nativas del Norte de Chile. Chile: Facultad De Ciencias; Instituto De Biología.

[29] Morrison, D., \& Ellis, J. (1997). Effects of Nucleotide Sequence Alignment on Phylogeny Estimation: A Case study of 18S rDNAs of apicomplexa. Mol. Biol. Evol, 14 (4), 428441 .

[30] Molins, A., Moya, P., García, F., Reig, J., \& Barreno, E. (2018). A multi-tool approach to assess microalgal diversity in lichens: isolation, Sanger sequencing, HTS and ultrastructural correlations. The Lichenologist, 50 (1), 123-138.

[31] Fawley, M. \& Fawley, K. (2004). A simple and rapid technique for the isolation of DNA from microalgae. Phycological Society of America, Volumen 40, pp. 223-225.

[32] Cruz, J. (2012). Comparación De Genes De Arn Ribosomal 18s De Tres Cepas Del Género Euglena: E. Pailasensis, E. Mutabilis Cpcc293 y Una Euglena Encontrada En Un Riachuelo Ácido Del Parque Nacional Volcán Rincón De La Vieja. Cartago: Instituto Tecnológico De Costa Rica.

[33] Baskara, A., Jayakumar, T., Ganasan, M., Mohan, N., Senthil, C., Nagaraj, S., Rengasamy, R., Manubolu, M., Sheu, J., \& Chang, C. (2018). Mass cultivation of new algae Tetraselmis straiata BBRR1 under open raceway ponds for biodiesel and biocrude production. Tamil Nadu, India: Preprints.

[34] Chin, W., Teoh, P., Anton, A. \& Kumar, S., (2018). Molecular Characterization And Identification Of Ribosomal Dna Sequences Of A Harmful Algal Bloom Species, Pyrodinium Bahamense Var. Compressum. Biotechnology Research Institute, 1 (1), pp. 1-8.

[35] Montes, J., \& Pulido, M. (2012). Obtención de protocolos para el aislamiento, cultivo y extracción de ADN de Chlorella vulgaris Beyerinck. Investigación y Ciencia del Gimnasio Campestre (45), 47-54.

[36] Galarza, J., Delgado, N., \& Henríquez, V. (2016). Cisgenesis and intragenesis in microalgae: promising advancements towards sustainable metabolites production. Publisher, Springer International Publishing. Applied Microbiology and Biotechnology, 100 (24), 10225-10235.

[37] Cagney, G., Amiri, S., Premawaradena, T., Lindo, M., \& Emili, A. (2003). In silico proteome analysis to facilitate proteomics experiments using mass spectrometry. Proteome Science, $1(1), 5$.

[38] Jiménez, J., \& Chaparro, A. (2016). In silico design and functional assessment of semisynthetic genes that confer tolerance to phosphinothricin. Revista Colombiana de Biotecnología, XVIII (2).

[39] Cienfuegos, A., Conn, J., Gomez, G., \& Correa, M. (2008). Diseño y evaluación de metodologías basadas en PCR-RFLP de ITS2 para la identificación molecular de mosquitos Anopheles spp (Diptera: Culicidae) de la Costa Pacífica de Colombia. Rev Biomed, 19 (1), 35-44. 